\title{
Recent benthic foraminifera in the Flensburg Fjord (Western Baltic Sea)
}

\author{
IRINA POLOVODOVA ${ }^{1,2, *}$, ANNA NIKULINA $^{2}$, JOACHIM SCHÖNFELD $^{2} \&$ WOLF-CHRISTIAN DULLO ${ }^{2}$ \\ ${ }^{1}$ University of Gothenburg, Department of Earth Sciences, PO Box 460, SE-405 30 Gothenburg, Sweden \\ ${ }^{2}$ Leibniz Institute for Marine Sciences, IFM-GEOMAR, Wischhofstrasse 1-3, D-24148 Kiel, Germany \\ *Corresponding author (e-mail: irina.polovodova@gvc.gu.se)
}

\begin{abstract}
Living benthic foraminifera of Flensburg Fjord were surveyed in June 2006. The muddy and organic-rich sediments of the inner fjord were dominated by Elphidium incertum. E. incertum and E. excavatum were frequent in muds and sandy muds of the fjord loop around Holnis Peninsula and in the outer part. Gelting Bay yielded a different biofacies, indicating a brackish and sandy habitat, poor in food supply and with microfauna dominated by Ammonia beccarii and E. albiumbilicatum. The central fjord and nearshore zones of the loop were characterized by sandy muds, relatively poor in food and occupied by $A$. beccarii, E. incertum and E. excavatum subspecies. High abundances of E. excavatum were encountered in the innermost fjord, with fine-grained and organic-rich muddy sediments.

A comparison with previous studies revealed the profound changes in species composition in the outer Flensburg Fjord since the 1970s. A decline in numbers of Ammotium cassis and flourishing of Ammonia beccarii in Gelting Bay were recognized. These changes are most likely associated with decreased intensity and frequency of salt-water inflows into the Baltic Sea since the 1960s. It is inferred that the decline of $A$. cassis is similar to that of Eggerelloides scaber, which currently is found only in depressions of Kiel Bight with higher salinity. J. Micropalaeontol. 28(2): 131-142, November 2009.
\end{abstract}

KEYWORDS: benthic foraminifera, salinity, oxygen depletion, foraminiferal cysts, Baltic Sea

\section{INTRODUCTION}

Foraminifera in the Baltic Sea have been investigated since the nineteenth century (Schulze, 1875; Möbius, 1889; Levander, 1894). The first studies with a taxonomical identification of foraminifera in Kiel Bight were made by Rhumbler (1936), who found 49 genera and 71 species. Studies on foraminiferal ecology in the SW Baltic Sea, initiated by Rottgardt (1952), established temperature and salinity as the most important controlling ecological factors for benthic foraminifera, whereas substrate was assumed to be of minor significance (Lutze, 1965). Later, previously ignored substrate features, together with hydrodynamics and oxygen content of the bottom water, were considered by Wefer (1976), who found them to be important factors regulating foraminiferal abundances in the open Kiel Bight. Some species in the central and south-western Baltic were shown to be especially sensitive to salinity changes caused by saline bottom water inflows from the Kattegat (Lutze et al., 1983; Hermelin, 1987; Schönfeld \& Numberger, 2007a; Nikulina et al., 2008). In particular, Lutze et al. (1983) observed an arenaceous foraminifer Eggerelloides scaber only in depressions of the Kiel Bight due to its preferences for higher salinity. For the central Baltic Sea, it was shown that a northward decrease in salinity, temperature and oxygen content is reflected by reduced benthic foraminiferal diversity and abundances (Hermelin, 1987). Kreisel \& Leipe (1989) described only four species in the Bay of Greifswald and suggested that such low species richness might also be explained by brackish conditions. A decrease in salinity as a background reason for the decline of Ammotium cassis across the Kiel Bight was suggested by Schönfeld \& Numberger (2007a) and Nikulina et al. (2008). These authors assumed that reduced salinity prevents formation of a stable halocline, which is necessary to provide a high supply of suspended food particles - essential for the feeding of $A$. cassis (Olsson, 1976).
Lack of food is generally considered as one of the main constraints on foraminiferal abundances (Murray, 2006). In Kiel Bight, limited food availability was observed to be of major importance for only two species: Ammotium cassis and Ophthalmina kilianensis, whereas all other foraminifera had enough food due to high productivity in the SW Baltic as compared to the adjacent ocean (Wefer, 1976). Feeding behaviour of foraminifera in Kiel Bight was studied by Heeger (1990) and Linke \& Lutze (1993), who also reported some adaptive mechanisms to gain more food under less favourable conditions, such as elevated microhabitats, change from epifaunal to infaunal mode and isolated chloroplasts in the protoplasm assumed to be an additional source of energy. Schönfeld \& Numberger (2007b) reported the 'bloom-feeding' strategy of E. excavatum clavatum in Kiel Bight, reflected in elevated pigment content in the protoplasm.

In spite of numerous investigations in the SW Baltic, foraminifera from the entire length of Flensburg Fjord (Fig. 1) have not been studied so far and this is the first description of living (stained) benthic foraminiferal assemblages from this area. Previous investigations either considered the total assemblages or were focused only on the central, or open, part of the fjord (Rottgardt, 1952; Exon, 1972). The inner fjord has not been considered previously. Because Flensburg Fjord is an inlet of Kiel Bight, which directly faces the salt-water inflows from the Kattegat, some foraminiferal taxa dwelling here may be very sensitive to occasional salinity fluctuations (Polovodova \& Schönfeld, 2008), while others may be well adapted. Therefore, Flensburg Fjord represents an appropriate study area for dynamic response of foraminifera to natural environmental perturbations.

The purpose of this study is to investigate the distribution of living (stained) benthic foraminifera in Flensburg Fjord with respect to environmental parameters of the bottom water and 


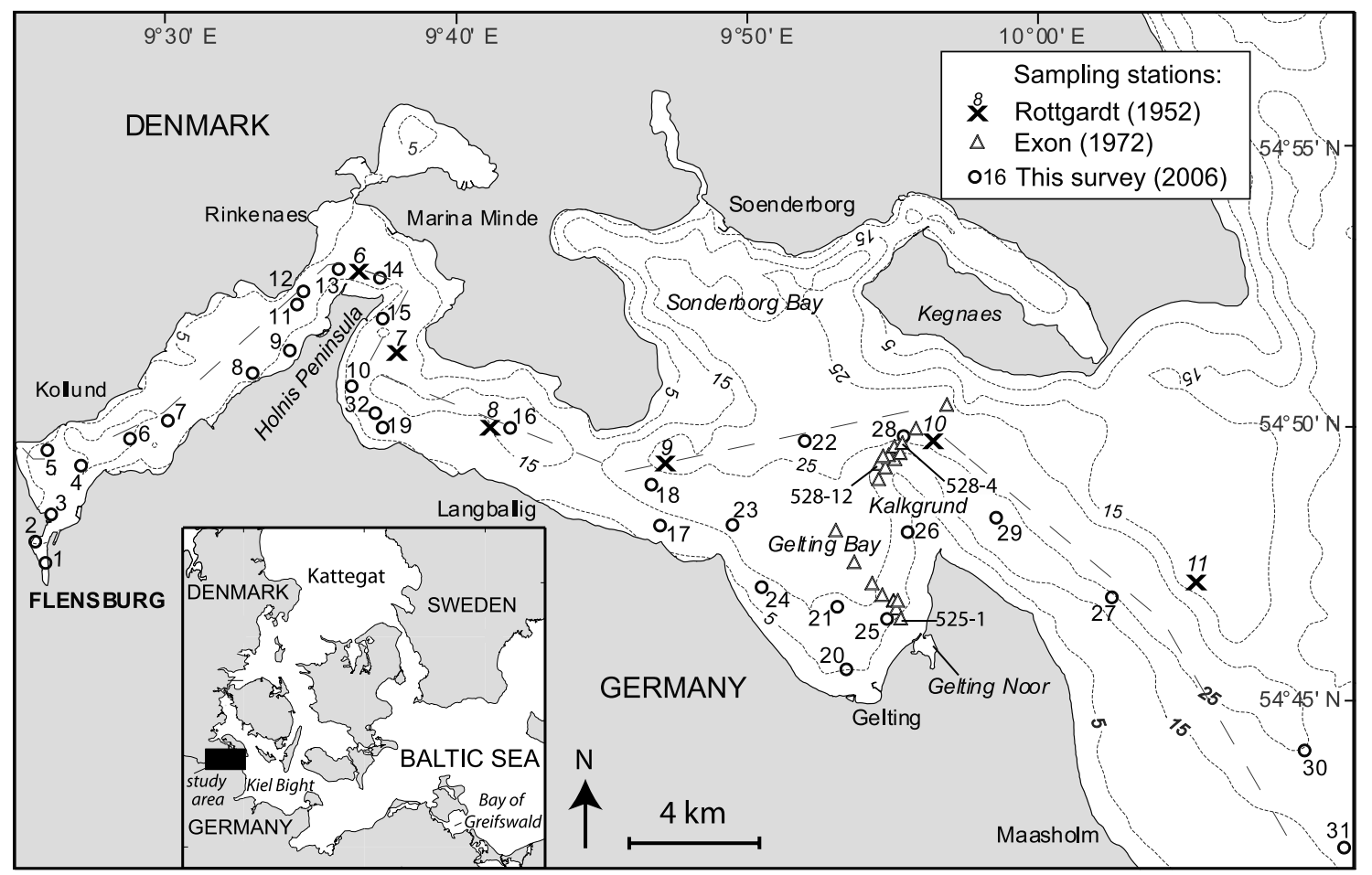

Fig. 1. Regional setting of Flensburg Fjord and positions of sampling sites. Black box indicates the location of study area within the SW Baltic. Prefixes 'PF16-' are not given here for the sake of convenience.

sediments. Further, these data are compared with previous studies in order to assess the changes in foraminiferal communities since the late 1940s and 1970s.

\section{STUDY AREA}

Flensburg Fjord is a narrow, $50 \mathrm{~km}$ long, W-E-trending inlet of the northwestern part of Kiel Bight (Fig. 1). The inner fjord, which is $10-20 \mathrm{~m}$ deep, is characterized by restricted water exchange with the Kiel Bight and the Baltic Sea over a sill of $10 \mathrm{~m}$ depth off Holnis Peninsula (Nikulina \& Dullo, 2009). The outer Flensburg Fjord comprises Sonderborg Bay with 13-31 m depth range, Gelting Bay (4-22 m deep) and open waters to the east of Gelting Peninsula. There is a considerably high depth range - from $5 \mathrm{~m}$ at Schleisand to $39 \mathrm{~m}$ in the Little Belt.

Flensburg Fjord is the most protected estuary in the region and wave action does not reach significant depth. Thereby, waves and currents play a major role in the shallow-water areas. They favour the erosion of cliffs and deposit the eroded material in the deeper waters of the outer fjord (GKFF, 1973). Destruction and transport of foraminiferal tests are of minor importance in sheltered depositional areas as compared to regions with enhanced sediment erosion. The sediments of the deeper basins in the outer fjord are dominated by sandy muds and silt, whereas in shallow coastal areas sand and muddy sand prevail (Exon, 1972; GKFF, 1973). The inner Flensburg Fjord has sediments composed of dark sandy mud and soft mud (Exon, 1972).

During the winter months, the inner fjord is well mixed at $6.5^{\circ} \mathrm{C}$ and shows a salinity of $21 \mathrm{psu}$. The water column has a pronounced stratification during summer. Surface water of $17.5^{\circ} \mathrm{C}$ on average and a salinity of $16.5 \mathrm{psu}$ overlies the bottom water of $11^{\circ} \mathrm{C}$ and $18 \mathrm{psu}$. Every summer, a stable thermocline develops at $8-9 \mathrm{~m}$ in the inner fjord (GKFF, 1973). In the outer fjord, a persistent pycnocline at 16-20 m (Exon, 1972) separates brackish surface water from salty deep water throughout the year. The upper boundary of the pycnocline coincides in the outer fjord with the effective depth of wave action and divides the sedimentary environments into non-depositional and depositional areas.

The stable stratification in the inner part, together with enhanced eutrophication in the 1970-1980s, was responsible for summer oxygen deficiency, which lasted several months without interruption (Wahl, 1985). Eutrophication of Flensburg Fjord was caused by high nutrient input from sewage outfalls (Rheinheimer, 1970) and fertilizers from the adjacent land (DDTFF, 1992; LANU, 2001). In spite of the absence of nutrient input since that time, high levels of nitrogen and total organic carbon have remained in the sediments (LANU, 2001).

\section{MATERIAL AND METHODS}

Thirty-two samples of the surface sediment were taken on two daily cruises of R/B Polarfuchs in June 2006. Access was limited to German territorial waters and therefore concentrated on the southern part of the fjord. The majority of the samples were retrieved with a Rumohr corer, which has a sampling tube of $56 \mathrm{~mm}$ inner diameter. A Van-Veen Grab of $250 \mathrm{~cm}^{2}$ surface area was used when sandy sediments were encountered.

Within minutes of sample retrieval, salinity, temperature and dissolved oxygen content of bottom water were measured on board with Oxi- and Conductivity meters (WTW Oxi323/325 and LF320). In order to avoid the bias produced by spatial 
patchiness in the range of $2 \mathrm{~m}^{2}$ in foraminiferal distribution (Lutze, 1968), the Rumohr corer was always deployed three times and the uppermost $1 \mathrm{~cm}$ of sediment was taken off on each deployment (Schönfeld \& Numberger, 2007a, b). This sampling strategy was based on previous observations in the SW Baltic Sea (Wefer, 1976) that more than $90 \%$ of living foraminifera are concentrated in first centimetre of sediments. When sampling with a Van-Veen Grab, cut-off syringes marked with a centimetre scale were gently pushed vertically into the sediment to sample the top centimetre. The samples from all three deployments (about $25 \mathrm{~cm}^{3}$ of wet volume each) were collected in a glass vial, carefully mixed and sub-sampled for organic and inorganic geochemical analyses. The remaining $45 \mathrm{~cm}^{3}$ of sediment were transferred to a PVC vial, then preserved and stained with a Rose Bengal-ethanol solution $\left(2 \mathrm{~g}^{-1}\right)$ for foraminiferal studies.

The foraminiferal samples were first passed through a $2000 \mu \mathrm{m}$ screen in order to remove bivalve shells or pebbles and then they were gently washed with tap water through a $63 \mu \mathrm{m}$ sieve. Both fractions $(63-2000 \mu \mathrm{m}$ and $>2000 \mu \mathrm{m})$ were dried at $60^{\circ} \mathrm{C}$. Only well-stained foraminifers, presumed as living at the time of sampling (Murray \& Bowser, 2000), were picked out from respective aliquots, sorted at the species level and mounted in Plummer cell slides with glue. Dead assemblages were not considered in this study to avoid taphonomic bias. The main species were photographed using scanning electronic microscopes JSM-6460LV (St Petersburg State Mining Institute) and Cam Scan CS-44 (Institute of Geosciences, Kiel University). In comparison with Cam Scan CS-44, JSM-6460LV allows one to observe the natural test surface without electric 'noise' on the images due to operation at low vacuum (30 Pa) with no metal or graphite coating of the samples (Widerlund \& Andersson, 2006). Graphite glue was used to mount the foraminiferal tests on the aluminium stabs prior to observation with JSM-6460LV, whereas carbon adhesive tape was applied for sample preparation for the Cam Scan.

To avoid staining errors, at least 100 specimens were picked either dry or wet and counted as a representative sample for ecological studies with satisfactory reliability (Murray, 2006). Wet picking was applied in sand-rich samples to facilitate the recognition of stained specimens.

For the species proportions, the standard binomial error was calculated (Fatela \& Taborda, 2002). In order to avoid bias associated with a constant sum constraint due to the low number of species in our samples, the percentage data were log-ratio transformed, following Kucera \& Malmgrem (1998). After data transformation, Q-mode cluster analysis was performed to distinguish different groups and biofacies of living benthic foraminifera. The statistics software Statistica 6.0 was used, and only the most abundant foraminiferal species with abundances higher than 5\% were considered in the cluster analysis. The applied clustering method was complete linkage and Euclidean distances (Vance et al., 2006). The resultant groups of samples are considered to represent different biofacies. The groups were defined by taking into account the significance level of linkage distance. We also considered the average percentages of species within each sample group in order to discern the different ecological groups of foraminifera, which characterize a certain biofacies.
The geochemical data are reported in detail by Nikulina \& Dullo (2009) and are used here for comparison only.

\section{RESULTS}

\section{General trends in foraminiferal distributions}

Living populations and surface-sediment assemblages are useful tools to assess the current state of a benthic ecosystem (Hallock, 2000). In the case of benthic foraminifera, ecological studies should be based on living (stained) assemblages (Murray, 2006), because dead or total assemblages do not reflect the current environmental conditions due to taphonomic alterations. To describe the current foraminiferal distribution and ecology in Flensburg Fjord and to assess the response of these organisms to recent environmental changes, only living (stained) foraminifera were considered in this study. Ten taxa ( 8 calcareous, 2 arenaceous) were identified at 31 of 32 stations; one station (PF15-09) was barren of living foraminifera.

The standing stock of benthic foraminifera varied greatly: from 11 to 3130 individuals per $10 \mathrm{~cm}^{3}$ (Fig. 2a). Numbers lower than 20 living specimens per $10 \mathrm{~cm}^{3}$ occurred in the innermost fjord and off Gelting Peninsula. The highest standing stock values of more than 3000 individuals per $10 \mathrm{~cm}^{3}$ were recorded in the outer part of the Flensburg Fjord.

Assemblages were dominated by Elphidium incertum, Ammonia beccarii, and E. excavatum excavatum (28\%, 25\% and $25 \%$, respectively, on average). E. excavatum clavatum and E. albiumbilicatum were common $(12 \%$ and $10 \%$, respectively, on average). Ammotium cassis, Reophax dentaliniformis regularis, $E$. williamsoni, E. gerthi and E. gunteri were rare (maximal 2\%). The inner fjord was characterized by a predominance of $E$. incertum (Figs 2c, e) with a small proportion of E. excavatum excavatum. The foraminifer E. albiumbilicatum was encountered in high abundance (up to $56 \%$ ) in nearshore sandy areas of Gelting Bay (Fig. 2f) with enhanced coastal erosion and active sediment transport. Ammonia beccarii occurred in the central fjord and Gelting Bay (Fig. 2b) under conditions of reduced food availability. Both subspecies of E. excavatum showed the highest abundances in the open Flensburg Fjord (Figs 2c, d). The arenaceous species Ammotium cassis and Reophax dentaliniformis regularis tended to occur at stations with higher salinity, situated in the central and open parts.

Significant correlations between certain species, sediment type and food supply were revealed (Table 1). In particular, Ammonia beccarii and Elphidium albiumbilicatum correlated positively to the proportion of the sediment fraction $>63 \mu \mathrm{m}$ (sand content). Conversely, abundances of E. excavatum excavatum showed a negative correlation with sand content. In its turn, A. beccarii showed a negative correlation to food availability.

SEM images of foraminifera showed that some tests of Elphidium incertum were covered with particles, similar to sand grains (P1. 1, figs 14-15). Elphidium albiumbilicatum and E. excavatum clavatum encountered in Gelting Bay showed irregular mineralogical projections of unknown origin, which protruded from the test wall (Pl. 1, figs 7, 19). An intense perforation of Ammonia beccarii tests (Pl. 1, fig. 22) was found in central (PF16-21) and southern Gelting Bay (PF16-20), and in the open Flensburg Fjord (PF16-27). Elphidium albiumbilicatum 

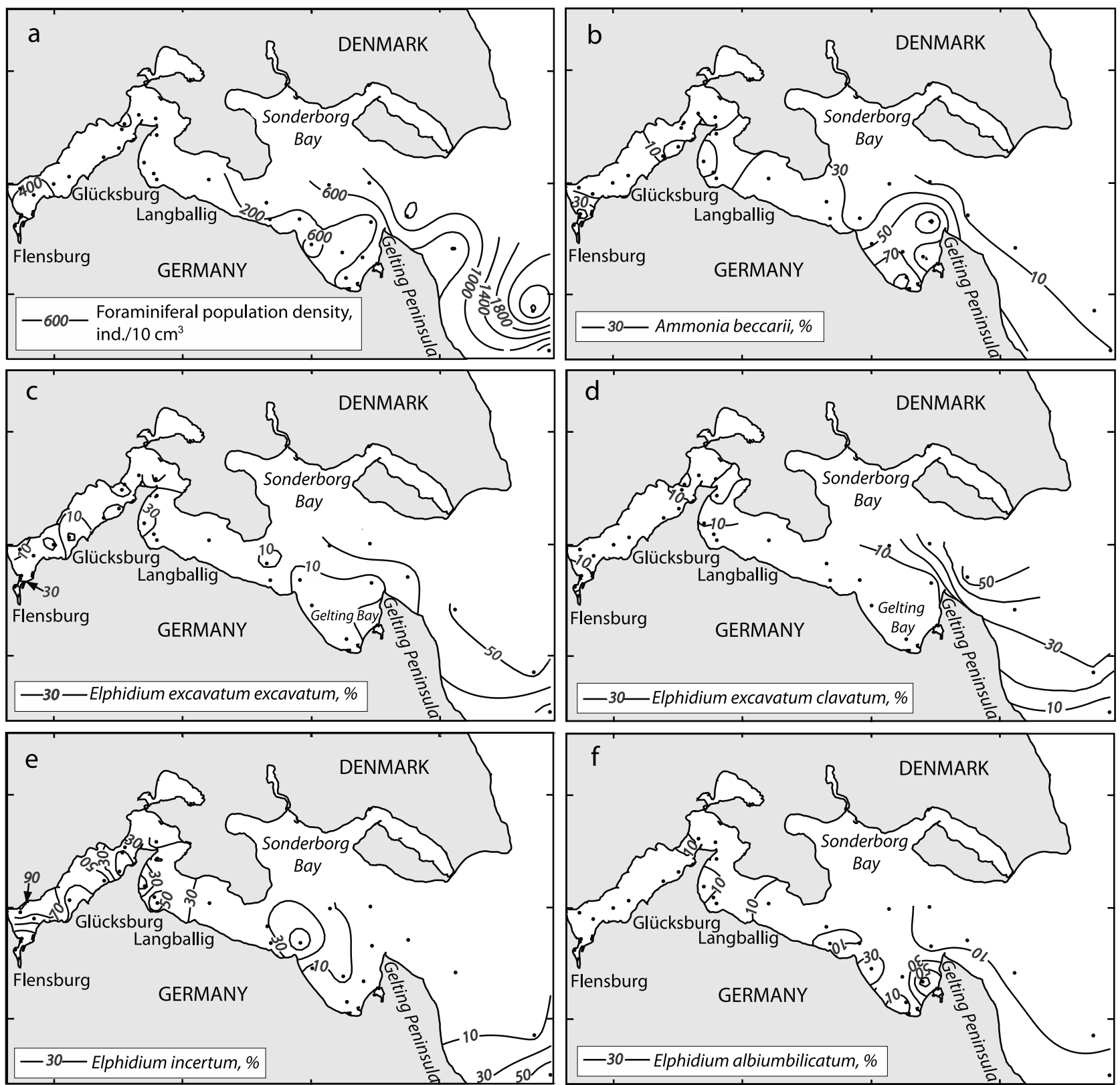

Fig. 2. (a) Benthic foraminiferal standing stock and (b)-(f) dominant species relative abundances (proportions) in the Flensburg Fjord. Black dots indicate the stations.

\begin{tabular}{|c|c|c|c|c|}
\hline Species & Environmental parameter & Correlation coefficient, (r) & Significance test $(\mathrm{T})$ & Quantile $\left(t_{n-2,1-\alpha}\right)$ \\
\hline \multirow[t]{4}{*}{ Ammonia beccarii } & Fraction $>63 \mu \mathrm{m}(\%)$ & $0.484(n=31)$ & 2979 & 1.699 \\
\hline & $\mathrm{SiO}_{2}(\mathrm{wt} \%)$ & $-0.684(n=31)$ & -5.049 & 1.699 \\
\hline & Chlorophyll- $a$ ( $\left.\mathrm{ng} \mathrm{g}^{-1}\right)$ & $-0.525(n=31)$ & -3.332 & 1.699 \\
\hline & Phaeopigments $\left(\right.$ ng g $\left.^{-1}\right)$ & $-0.700(n=31)$ & -5.279 & 1.699 \\
\hline E. excavatum excavatum & Fraction $>63 \mu \mathrm{m}(\%)$ & $-0.405(n=31)$ & -2385 & 1.699 \\
\hline E. albiumbilicatum & Fraction $>63 \mu \mathrm{m}(\%)$ & $0.417(n=31)$ & 2.471 & 1.699 \\
\hline
\end{tabular}

The significance test for a linear correlation at normal distribution of data was performed according to Aßmann et al. (2007). Note that a type-I error $\alpha=0.05$. All correlations, presented here, passed the significance test, i.e. have T-value in modulus higher than $t_{n-2,1-\alpha}$.

Table 1. Correlations between species abundances and environmental parameters in Flensburg Fjord. 


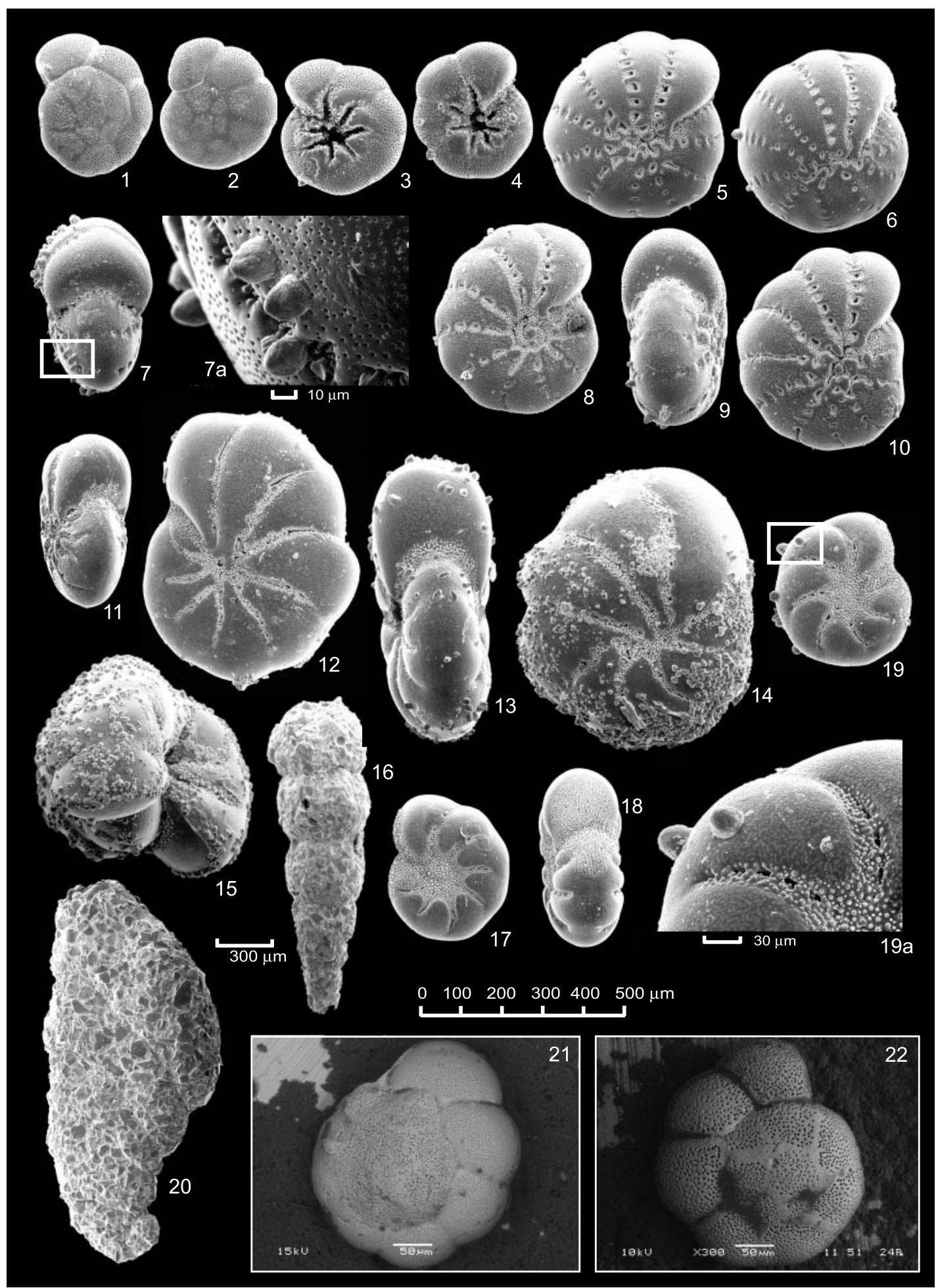

Explanation of Plate 1.

Some species of living benthic foraminifera from Flensburg Fjord. figs 1-4. Ammonia beccarii: 1, 2, spiral and 3, 4, umbilical views. figs 5-7. Elphidium excavatum clavatum: 5, 6, spiral view; 7, apertural view; 7a, detailed view of mineralogical projections. figs 8-11. Elphidium excavatum excavatum: 8, 10, spiral and 9, 11, apertural views. figs 12-15. Elphidium incertum: 12, spiral view; 13, apertural view and 14, 15, remains of the cyst at the test surface. fig. 16. Reophax dentaliniformis. figs 17-19. Elphidium albiumbilicatum: 17, 19, spiral view; 18, apertural view; and 19a, detailed view of mineralogical projections at the test surface. fig. 20. Ammotium cassis. Note that the $300 \mu \mathrm{m}$ scale belongs only to Ammotium cassis and Reophax dentaliniformis, while the $0-500 \mu \mathrm{m}$ scale is for the rest specimens (with the exception of the detailed views). figs 21-22. Uncoated SEM images of Ammonia beccarii with different test porosity. Note the smaller pores of a test from sample PF16-25 (21) as compared to the higher porosity of Ammonia test taken from PF16-20 (22). 


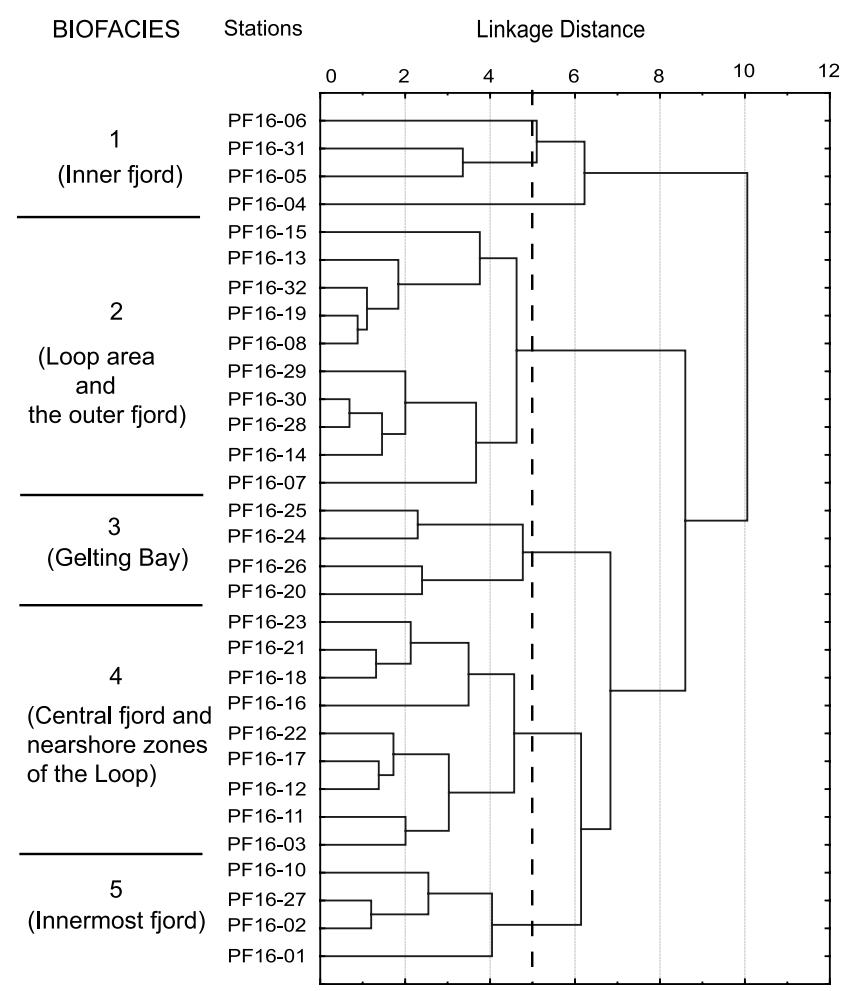

Fig. 3. Dendrogram produced by cluster analysis (complete linkage, Euclidean distance) of log-transformed percentages of living foraminifera. Dashed line indicates the significance level of the Euclidean distance according to a scree-plot.

showed numerous pustules in the apertural and umbilical area (Pl. 1, figs 17-19), which enable it to tolerate the intensive hydrodynamics due to a rough test surface (Nikulina et al., 2008).

\section{Q-mode cluster analysis}

The dendrogram (Fig. 3) is composed of several nesting groups, which here are grouped into five biofacies (Table 2, Fig. 4). Biofacies 1 (Elphidium incertum) is associated with muddy sediments and high food concentrations. Despite the fact that this biofacies is close to the limit of significance level, we consider it as one cluster based on relative abundances of the dominant species, which were higher than $50 \%$ at all stations. Biofacies 2 (co-dominant $E$. incertum and $E$. excavatum excavatum) occurred in muddy sediments with a high chlorophyll- $a$ content. Biofacies 3 (Ammonia beccarii) occurred in coarse sands, poor in food supply and overlain by highly oxygenated water. Biofacies 4 (A. beccarii) occurred in muddy sands. Biofacies 3 and 4 had differences in the proportions of the subsidiary species. Biofacies 5 (E. excavatum excavatum) occurred in muddy sediments. There were minor variations in species richness between the biofacies but major variations in both the average standing stock and the range of standing stock. This was especially recognized in biofacies 3 , where it ranged from 28-200 individuals per $10 \mathrm{~cm}^{3}$ in the loop area and $938-3130$ ind. $10 \mathrm{~cm}^{-3}$ in the outer fjord. Water temperature and salinity differences showed only minor variation between the biofacies.

\section{DISCUSSION}

\section{Food supply}

As a measure of food supply, we considered the sedimentary content of chlorophyll- $a$, biogenic silica and organic carbon. In general, the flux of organic carbon reaching the sea floor comprises labile material from recently dead plankton, refractory material both derived from plankton and having terrestrial origin, and faecal pellets from zooplankton (Murray, 2006). Nikulina \& Dullo (2009) reported the high levels of organic carbon, chlorophyll- $a$ and biogenic silica in sediments from the

\begin{tabular}{|c|c|c|c|c|c|c|}
\hline \multicolumn{2}{|c|}{$\begin{array}{l}\text { Benthic foraminiferal species and environmental } \\
\text { parameters }\end{array}$} & \multirow{2}{*}{$\begin{array}{c}\text { Biofacies } 1 \\
\text { Inner fjord } \\
3.1\end{array}$} & \multirow{2}{*}{$\begin{array}{c}\begin{array}{c}\text { Biofacies } 2 \\
\text { Loop area and } \\
\text { outer fjord }\end{array} \\
7.7\end{array}$} & \multirow{2}{*}{$\begin{array}{c}\text { Biofacies } 3 \\
\text { Gelting Bay } \\
65.6\end{array}$} & \multirow{2}{*}{$\begin{array}{c}\text { Biofacies } 4 \\
\begin{array}{c}\text { Central fjord \& } \\
\text { nearshore zones } \\
\text { of the loop }\end{array} \\
40.2\end{array}$} & \multirow{2}{*}{$\begin{array}{c}\text { Biofacies } 5 \\
\text { Innermost fjord } \\
12.8\end{array}$} \\
\hline \multirow{7}{*}{ Census data } & Ammonia beccarii & & & & & \\
\hline & Elphidium albiumbilicatum & 9.9 & 2.6 & 26.9 & 11.3 & 10.3 \\
\hline & Elphidium excavatum excavatum & 8.8 & 31.9 & 5.2 & 19.4 & 57.9 \\
\hline & Elphidium excavatum clavatum & 0.3 & 21.0 & & 7.9 & 18.3 \\
\hline & Counted specimens $(n)$ & 181 & 175 & 118 & 152 & 84 \\
\hline & Standing stock, ind. $10 \mathrm{~cm}^{-3}$, & 197 & 614 & 182 & 264 & 57 \\
\hline & average (range) & $(105-324)$ & $(28-3010)$ & $(11-254)$ & $(83-759)$ & $(21-142)$ \\
\hline \multirow{3}{*}{ Bottom water } & Temperature $\left({ }^{\circ} \mathrm{C}\right)$ & 8.3 & 8.3 & 12.7 & 8.6 & 9.6 \\
\hline & Salinity $(\% 0)$ & 22.3 & 23.5 & 18.6 & 22.5 & 21.3 \\
\hline & $\mathrm{O}_{2}$ saturation $(\%)$ & 55.5 & 58.9 & 99.0 & 61.2 & 58.3 \\
\hline
\end{tabular}

Note that only species with abundances higher than $5 \%$ are given.

Table 2. Average foraminiferal census data (\%) and environmental parameters in each biofacies. 


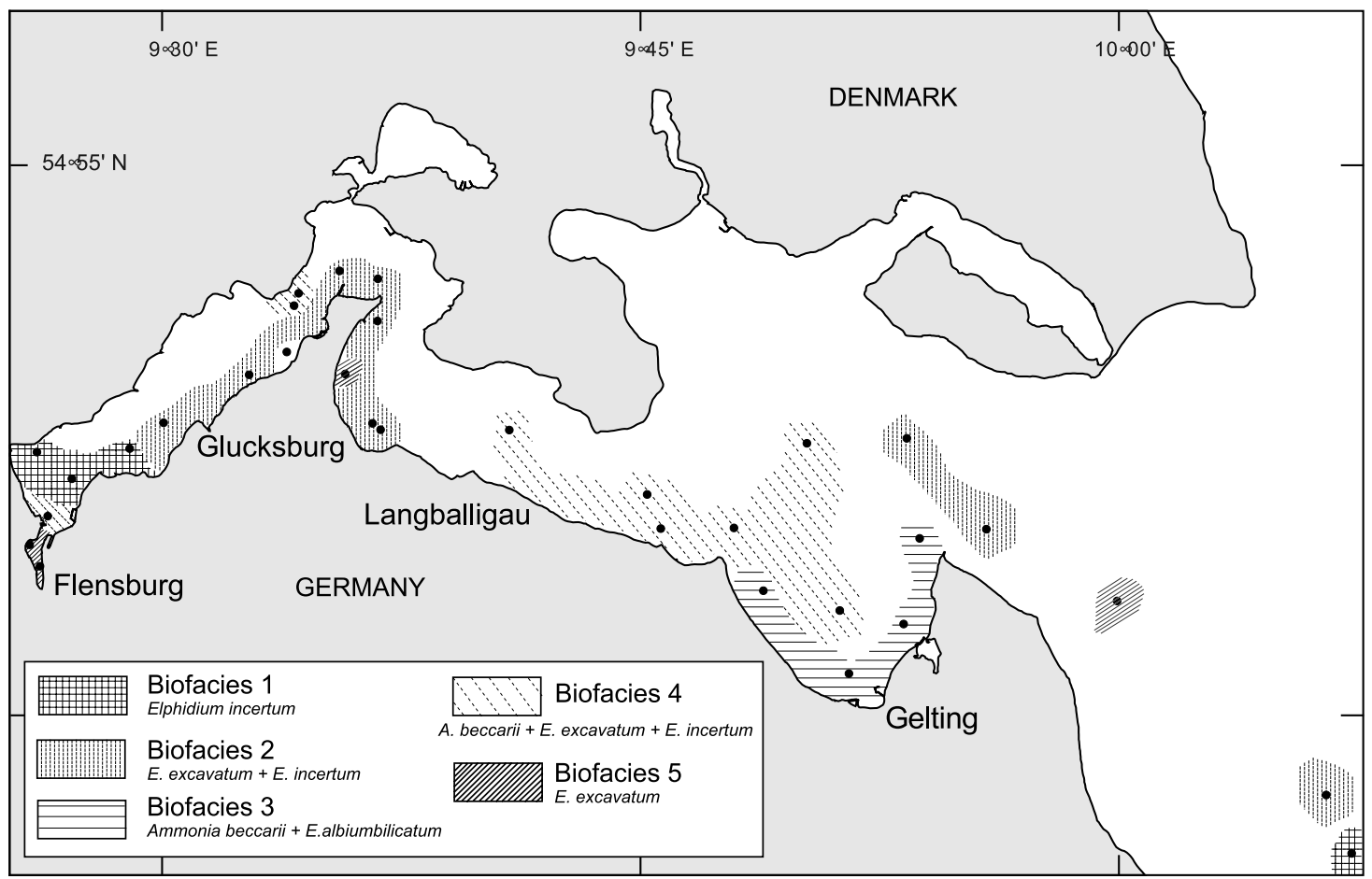

Fig. 4. Biofacies distribution of living benthic foraminifera in Flensburg Fjord as distinguished by sample groups of the cluster analysis. Black dots indicate the stations. Note the absence of the edge in all biofacies: it indicates the uncertainty of this plot, because it is based only on 32 stations and some biofacies may have spatial continuation in places that were not covered by the sampling net.

inner Flensburg Fjord, which mirrored phytoplankton bloom deposition. The phytoplankton in this area mainly consisted of diatoms (Schönfeld \& Numberger, 2007b). These observations allow us to consider the above-mentioned parameters as a measure of food available for benthic foraminifera in the study area.

Established correlations between some foraminiferal species, food supply and sediment type also point out the preservation capability of sediments. In particular, Ammonia beccarii and Elphidium albiumbilicatum tended to occur in sands of Gelting Bay, where, due to the absence of nutrient recycling from bottom sediments (Exon, 1972) and high hydrodynamic activity, lower productivity and a lack of food supply take place. Conversely, Elphidium incertum was found in the inner fjord where higher productivity, regular oxygen depletion, restricted current regime and muddy sediments enriched in organic matter were encountered (Nikulina \& Dullo, 2009).

These observations strengthen the idea that at least some benthic foraminiferal species of the Flensburg Fjord are fooddependent. On the other hand, no correlations were found of standing stock with distribution of organic carbon, chlorophyll- $a$ and biogenic silica. This relationship is often complicated by the covariance of organic carbon with other factors, such as sediment grain size and geochemistry in marginal environments (Murray, 2006). The latter two factors are closely coupled, because sediment grain size determines food preservation and accumulation in the sediments, as well as nutrient recycling and formation of certain redox conditions, which affect productivity, in turn.

\section{Reliability of foraminiferal abundances}

An accuracy of foraminiferal abundances in sediment samples is usually dependent on sampling protocols and processing of the samples. To obtain reliable data, more than one sample from the same site has to be taken to avoid the bias associated with patchiness of foraminiferal distribution (Murray, 2006). In this study, the pooling of three replicate core top samples was done in order to minimize the bias induced by spatial patchiness. The scale of patchiness in the study area is in the order of $2 \mathrm{~m}^{2}$ (Lutze, 1968). With ship motion of 1-3 m during station work, a replicate sample was most likely retrieved from a place at the seabed where the foraminiferal population structure differed from the place where the first sample came from. Therefore, we had to combine the replicates in order to obtain samples that were representative of the sampling site on a local scale. As the volumes of the replicates were equal, pooling was considered to create a much more representative sample for foraminiferal and geochemical studies than a later combination of the analyses from the individual replicates. Furthermore, such replicate analyses might have been created from splits of a different size, leading to a different contribution of the individual samples.

Staining of foraminiferal protoplasm with Rose Bengal was discussed in the literature as a method that has to be handled with caution because it does not allow differentiation between living and decaying individuals, leading to overestimations of species' abundances (Bernhard, 1988; Corliss \& Emerson, 1990). The alternative methods for Rose Bengal are fluorescent probes MTT and Cell Tracker Green (Bernard et al., 2006; De Nooijer et al., 2006), which are more accurate in abundance assessment 
but usually hamper comparison with previous studies and ignore the foraminifera that do not survive sampling (De Nooijer et al., 2008). Cell Tracker Green also requires the immediate processing of a sample with high instrumental (UV-light) and preparational (wet picking under dark conditions) efforts (J. Bernhard, pers. comm.). Conversely, Rose Bengal staining has been, and still is, widely used in an increasing number of studies. The method is easy in handling and able to give results which are up to $96 \%$ correct (Lutze \& Altenbach, 1991), if applied with long-standing practice and understanding of its limitations (Murray \& Bowser, 2000). Therefore, we consider an accurate handling of Rose Bengal staining to be able to produce reliable data of living (stained) foraminiferal abundances.

\section{Predominance of Elphidium incertum in the inner Flensburg Fjord}

In this study, we observed Elphidium incertum as highly abundant in muddy sediments of the inner Flensburg Fjord, associated with higher concentrations of $\mathrm{C}_{\text {org }}(6-11 \%)$ and biogenic silica $(3-10 \%)$ and relatively low sedimentary chlorophyll- $a$ (43-189 $\mu \mathrm{g} \mathrm{g}^{-1}$ ). Some authors (Altenbach, 1985; Gustafsson \& Nordberg, 1999) found increased amounts of this species after the spring phytoplankton bloom, which delivered fresh food to the sediment surface. We did not find any correlations of $E$. incertum with biogenic silica, chlorophyll- $a$ and $\mathrm{C}_{\text {org. }}$. Apparently, there must be other factors that determine the distribution of this species in Flensburg Fjord. As was shown for Koljö Fjord, a freshly deposited phytoplankton is of less importance for $E$. incertum, when oxygen conditions become unfavourable (Gustafsson \& Nordberg, 1999).

Elphidium incertum was described as an infaunal species, which does not dwell exclusively at the sediment surface but down to 3-6 cm (Linke \& Lutze, 1993). However, if sediments become uninhabitable due to a very shallow redox boundary, this species may be found at the sediment surface (Wefer, 1976). Rottgardt (1952) mentioned the absence of the uppermost brownish oxidized layer in the sediments at the station off the Holnis Peninsula, although bottom waters were sufficiently oxidized with $278 \mu \mathrm{mol} 1^{-1}$ in May 1949. During sampling in 2006, the oxygen concentration at station PF16-14 was lower $\left(178 \mu \mathrm{mol} 1^{-1}\right)$, although saturation exceeded $50 \%$. The establishment of a redox boundary occurs in Flensburg Fjord every year due to oxygen deficiency of bottom waters from May to October under the presence of a stable pycnocline at 6-12 m depth (Jarke, 1961; Kremling et al., 1979; Wahl, 1984, 1985; LANU, 2007). Thus, we conclude that high abundances of $E$. incertum within the uppermost sediment layer in the inner Flensburg Fjord were most likely related to oxygen deficiency in sediments just before the sampling time.

Moreover, some authors (Wefer, 1976; Linke \& Lutze, 1993) reported encystment of Elphidium incertum as a strategy of dormancy during anoxic periods. Gustafsson \& Nordberg (1999) observed cocooned E. incertum tests at the stations, where Beggiatoa bacterial mats indicate the presence of a redox boundary at the sediment surface. Such cysts or cocoons are quite resistant and were sometimes still intact after sample processing (Wefer, 1976). In this study, we observed the remains of the cysts firmly attached to tests of Elphidium incertum (Pl. 1, figs 14-15), even though all samples were thoroughly washed.
The same phenomenon was mentioned by Exon in his notes on the 1970s foraminiferal survey as a peculiar feature of $E$. incertum tests in the outer Flensburg Fjord. Hence, we infer that our sampling campaign had followed a short anoxic period, which led to an extremely high abundance of E. incertum in the uppermost sediment layer.

Evidence for oxygen deficiency in sediments of the Gelting Bay? Though hydrographical data did not indicate an oxygen deficiency in the bottom water during the sampling period, the southern part of Gelting Bay was previously reported as a quiet area exposed to relatively low oxygen and nutrient content (Exon, 1972). Moodley \& Hess (1992) showed that Ammonia beccarii developed an adaptation reflected in higher test porosity under the lack of oxygen. Indeed, we observed larger pores in $A$. beccarii in southern Gelting Bay than anywhere else in the fjord. This may be seen as an adaptation to provide an adequate gas exchange under low oxygen conditions, which might have taken place before sampling. In order to test this conclusion, we calculated the 'Ammonia beccarii-Elphidium excavatum subspecies' index (A/E Index), used as a proxy of hypoxia for the Louisiana Bight by Sen Gupta et al. (1996). It showed the highest values at four stations in the Gelting Bay: PF16-20 (98\%), PF16-21 (91\%), PF16-24 (96\%) and PF16-26 (100\%). According to Brunner et al. (2006), an index value $>80 \%$ indicates hypoxic conditions, whereas an $\mathrm{A} / \mathrm{E}<50 \%$ is typical for clearly oxic samples. Though, the A/E values $>90 \%$ at stations PF16-20 and PF16-21 coincide with encountered enhanced porosity, the sandy sediments and low concentrations of $\mathrm{C}_{\text {org }}$, chlorophyll- $a$ and biogenic silica (Nikulina \& Dullo, 2009, fig. 3) do not provide the pre-conditions for oxygen deficiency in sediments. At the same time, the $A / E$ Index is apparently not applicable as an oxygen proxy in an area and a climatic zone so different from the Mississippi and Louisiana Bight (Brunner, pers. comm., 2008). In this case, the reason for enhanced porosity of Ammonia tests observed only in southern Gelting Bay remains enigmatic.

\section{Comparison with previous studies}

Abundances of foraminiferal assemblages at six stations sampled in Flensburg Fjord in October 1949 (Rottgardt, 1952) were compared to our abundances at stations located nearby. The comparison was hampered by differences in methodology. Rottgardt (1952) considered the total (living plus dead) foraminiferal fauna from grab samples, comprising several centimetres of sediment, whereas we investigated the living (stained) assemblages in the uppermost sediment layer $(0-1 \mathrm{~cm})$. Nevertheless, we can derive information about the occurrence and dominance of different species in 1949 and reveal how the foraminiferal assemblages in Flensburg Fjord have changed since that time. Regarding previous studies conducted in Kiel Bight (Wefer, 1976), which proved a minor interannual and yearly variability in the proportion of dominant species, it appears justified to draw some limited conclusions despite different sampling seasons.

According to Rottgardt's (1952) results, Elphidium excavatum subspecies were the dominant element of the fauna in the Holnis Shoal (his station 6), whereas Ammonia beccarii and E. incertum were common. These results agree with our observations. In the central part of Flensburg Fjord (stations 7, 8, 9), 
Elphidium incertum was a dominant faunal element in 1949, while Elphidium excavatum subspecies and Ammonia beccarii prevailed in the central fjord in 2006. Samples from the outer fjord (10 and 11) were incredibly rich in tests $(>1000)$ of Eggerelloides scaber in 1949. In 2006, however, we did not observe any E. scaber at stations PF16-28 and PF16-27 from the outer fjord. Elphidium excavatum subspecies were the dominant elements of the recent foraminiferal fauna here. Also, we found a few living individuals of Ammotium cassis - a species that was not reported by Rottgardt in 1949.

In October 1970, benthic foraminifera in the outer Flensburg Fjord were investigated by Exon (1972). He established two profiles of stations in an outer fjord (Fig. 1). The first profile extended from the shallow to the deeper parts of the southern Gelting Bay. The second one was situated in the outer part, eastward of Kalkgrund (a shallow-water area around Gelting Peninsula). Exon's (1972) methods were very similar to ours. He worked with grab samples, from which the uppermost centimetre of sediment was removed, stained with Rose Bengal and studied for living (stained) and dead foraminifera. An exception represents the way in which Exon expressed the values of population density: he weighed wet samples and calculated foraminiferal population densities in individuals per $10 \mathrm{~g}$ of wet sediments. This protocol makes our data on standing stock incomparable with those from the 1970 s survey. In order to ascertain how living foraminiferal assemblages have changed since the 1970s, we recalculated the percentages of species, observed as living in 1970, from the archive material stored at the Institute of Geosciences (University of Kiel). Unfortunately, only two of Exon's (1972) stations, 525-1 and 528-4, can be compared to our data because they were located next to our stations PF16-25 and PF16-28.

According to Exon (1972), a southern Gelting Bay profile extended from $8 \mathrm{~m}$ to $22 \mathrm{~m}$ and did not exhibit any living individuals of foraminifera at the deepest station. At the shallow-water station 525-1, an arenaceous Ammotium cassis was found as a dominant species $(83.9 \%)$ and all other species (including Ammonia beccarii) were rare. Conversely, our survey showed a clear dominance of Elphidium albiumbilicatum (56\%) and $A$. beccarii (25\%) at station PF16-25; Elphidium excavatum subspecies were common $(17 \%) ; E$. incertum and $A$. cassis were rare $(1 \%)$.

In the outer Flensburg Fjord, the only station with a predominance of Ammotium cassis $(96 \%)$ and rare occurrence of Ammonia beccarii (1\%) was site 528-12, whereas at all other stations Elphidium incertum prevailed (Exon, 1972). At station 528-4, E. incertum was dominant and E. excavatum was common. As compared to the 1970s, our station PF16-28 (Appendix B) showed a clear dominance of E. excavatum subspecies (together $87 \%$ ) with $A$. beccarii as common $(6 \%)$ and other species (E. incertum, E. albiumbilicatum, E gunteri and A. cassis) as rare (maximum $4 \%$ ).

\section{Changes in species composition}

The usage of the total fauna (living plus dead) makes comparisons of species composition from different studies difficult due to post-mortem changes in a population. This relates in particular to test destruction and transport (Murray, 1989; 2006). Almost all of Rottgardt (1952) stations, considered in this study, are situated within sheltered depositional areas of Flensburg Fjord, where muddy sediments prevailed. Furthermore, the Baltic Sea is undersaturated with respect to calcium carbonate (Jarke, 1961; Grobe \& Fütterer, 1981) and calcareous tests are dissolved within a few weeks after death (Hermelin, 1987). The high abundances of calcareous foraminifera in total assemblages indicate either the high productivity of certain species, or their dominance in the assemblage while they were alive.

In this study, we observed a decline in Ammotium cassis and a flourishing of Ammonia beccarii in shallow areas of Gelting Bay, as compared to the previous study of Exon (1972). Only isolated individuals of $A$. cassis were found in Gelting Bay and in the outer fjord. The extraordinary high abundances of $A$. cassis in the $1970 \mathrm{~s}$ in the uppermost centimetre of sediments reflected a situation lasting at least 3.7 years (from 1966 to 1970), if we apply a sedimentation rate in Gelting Bay of $2.7 \mathrm{~mm}$ $\mathrm{a}^{-1}$ (Müller et al. 1980, fig. 2). Indeed, changes in species composition since the 1970s are similar to those we observed in Kiel Fjord (Nikulina et al., 2008), where living A. cassis was abundant in the 1960s (Lutze, 1965) and is absent today.

In shallow areas of Gelting Bay, it was reported that the widespread colonization of Ammonia beccarii takes place above the discontinuity layer but never below it (Exon, 1972). In its turn, maximum abundances of Ammotium cassis were found in association with the presence of a halocline, which provides a high input of particulate organic matter (Olsson, 1976), or within sediments where the redox boundary sustains high bacterial numbers (Linke \& Lutze, 1993). The introduction of this species into the Baltic Sea took place between 1935 and 1952 (Lutze, 1965), and it was frequent in Kiel Bight between the early 1960s and mid-1980s (Schönfeld \& Numberger, 2007a). In Flensburg Fjord, Ammotium cassis was not reported by Rottgardt (1952) in the late 1940s. It is likely that due to the lower frequency, or intensity, of salt-water inflows from the North Sea in the past decades (Matthäus, 2006), the establishment of a stable discontinuity layer - a necessary condition for nutrition of Ammotium cassis - was impeded and, therefore, this species became extremely rare in the outer Flensburg Fjord. This pattern was shown previously for Eckenförde Bay (Schönfeld \& Numberger, 2007a) and Kiel Fjord (Nikulina et al., 2008). Taking into account a preference of Ammotium cassis to dwell close to discontinuity layers in the sediment column (redox boundary) and at the sediment-water interface (halocline), we conclude that both niches are currently occupied by more tolerant and opportunistic Elphidium incertum in the inner fjord and Ammonia beccarii in Gelting Bay.

At the same time, isolated specimens of Ammotium cassis, observed in the outer parts of Flensburg Fjord in 2006, require explanation. Do they represent a relict population, survivors of the periods of lower salinity, or are they forerunners of the reintroduction of this species? To answer these questions, further monitoring of foraminiferal assemblages in the Kiel Bight and, in particular, Flensburg Fjord is needed.

\section{Absence of Eggerelloides scaber \\ Eggerelloides scaber was reported by Lutze et al. (1983) as a species whose distribution does not depend directly on the substrate type, or bottom topography in the SW Baltic. This species does require salinity conditions of at least 24 psu lasting}


most of the year. Rottgardt (1952) reported high abundance of Eggerelloides scaber in samples taken in the outer Flensburg Fjord. In 1960-1970s, Eggerelloides was virtually absent in the outer fjord (Exon, 1972; Lutze et al., 1983) and we also did not observe this species in 2006. The absence of living Eggerelloides scaber in our study apparently reflects the reduction of salt-rich Kattegat water inflows to the Western Baltic, as similarly shown by Lutze et al. (1983) for marginal basins of Kiel Bight.

\section{CONCLUSIONS}

Comparison with previous studies from the late 1940s and 1970s revealed apparent changes in species composition in the outer Flensburg Fjord: a decline in arenaceous Ammotium cassis, a flourishing of calcareous Ammonia beccarii in Gelting Bay and a dominance of Elphidium incertum in the inner fjord. These changes are similar to those reported recently from other fjords of the SW Baltic Sea (Eckenförde Bay and Kiel Fjord) and are most likely associated with the generally decreased intensity and frequency of major Baltic inflows since the 1960s, caused by larger fresh water supply from the catchment area and changes in atmospheric circulation over the north Atlantic during the past decades (Meier et al., 2006).

Five foraminiferal biofacies were distinguished in Flensburg Fjord. Their distribution appears to be controlled mainly by sediment grain size and food availability, while oxygenation of bottom waters is not a limiting factor for foraminifera. Correlations of some species to grain-size and food particles support the idea about role of grain size and food in distribution of benthic foraminifera in the Flensburg Fjord. The inner Flensburg Fjord (Biofacies 1) was dominated by Elphidium incertum dwelling within muddy sediments rich in organic matter. Biofacies 2 comprised the ' $E$. incertum-E. excavatum' group, which was found in the muds and sandy-muds of the fjord loop around Holnis Peninsula and the outer fjord with less food availability. Gelting Bay reflects a distinctly different area, with a shallow-water, brackish and sandy habitat poor in food particles. This area comprises the assemblage of Biofacies 3, dominated by opportunistic Ammonia beccarii and Elphidium albiumbilicatum. A. beccarii and E. incertum were dominant in the central Flensburg Fjord and nearshore zones of the loop around the Holnis Peninsula (Biofacies 4), with sandy muds relatively poor in food particles. Elphidium excavatum subspecies inhabited the innermost part of the fjord (Biofacies 5), with the fine-grained muddy sediments rich in food.

It was suggested that the frequent occurrence of the infaunal Elphidium incertum in the uppermost sediment layer might reflect the seasonal anoxic conditions in sediments of the inner Flensburg Fjord, which preceded the sampling period. It appears, however, that an A/E index - an indirect hypoxia proxy - is not applicable for the SW Baltic Sea.

\section{ACKNOWLEGEMENTS}

The authors are grateful to the crew of RV Polarfuchs, Holger Meyer and Helmut Schramm for help with sampling. They acknowledge Udo Laurer (IFM-GEOMAR), Ute Schuldt, Brigitte Salomon (Institute of Geosciences, Kiel) and Irina Gembitskaya (St. Petersburg State Mining Institute) for technical assistance. Thanks also go to Wolfgang Kuhnt, who provided access to the archives of the Institute of Geosciences and made Exon's archive data available. We also appreciate the constructive comments and interesting suggestions of J.W. Murray and L. de Nooijer, who reviewed the earlier version of the manuscript. This study was financed by Leibniz Award DFG DU 129-33 and a Scholarship of German Academical Exchange Survice (DAAD).

\section{Manuscript received 12 May 2008 Manuscript accepted 28 July 2009}

\section{REFERENCES}

Altenbach, A.V. 1985. Die Biomasse der benthischen Foraminiferen. Auswertungen von "Meteor"-Expeditionen im östlichen Nordatlantik. PhD, University of Kiel, Germany, 167 pp.

Aßmann, C., Golosnoy, V. \& Hogrefe, J. 2007. Formelsammlung zur Methodenlehre der Statistik II, $\beta$-version. Institut für Statistik und Ökonometrie der CAU Kiel, Germany, 63 pp.

Bernhard, J.M. 1988. Postmortem vital staining in benthic foraminifera: duration and importance in population and distributional studies. Journal of Foraminiferal Research, 18: 143-146.

Bernhard, J.M., Ostermann, D.R., Williams, D.S. \& Blanks, J.K. 2006. Comparison of two methods to identify live benthic foraminifera: a test between Rose Bengal and Cell Tracker Green with implications for stable isotope paleoreconstructions. Paleoceanography, 21: PA4219, DOI: 10.1029/2006PA001296

Brunner, C.A., Beall, J.M., Bentley, S.J. \& Furukawa, Y. 2006. Hypoxia hotspots in the Mississippi Bight. Journal of Foraminiferal Research, 36: $95-107$.

Corliss, B.H. \& Emerson, S. 1990. Distribution of Rose Bengal stained deep-sea benthic foraminifera from the Nova Scotian continental margin and Gulf of Maine. Deep-Sea Research, 37: 381-400.

DDTFF, 1992. Deutsch-Dänische Technikergruppe für die Flensburger Förde: Jahresbericht 1992, Apenrade, 42 pp.

De Nooijer, L.J., Duijnstee, I.A.P., Bergman, M.J.N. \& van der Zwaan, G.J. 2008. The ecology of benthic foraminifera across the Frisian Front, southern North Sea. Estuarine, Coastal and Shelf Science, 78: 715-726.

De Nooijer, L., Duijnstee, I.A.P. \& van der Zwaan, G.J. 2006. A novel application of MTT reduction: a viability assay for temperate shallow-water benthic foraminifera. Journal of Foraminiferal Research, 36: 195-200.

Exon, N. 1972. Sedimentation in the outer Flensburg Fjord area (Baltic Sea) since the last Glaciation. Meyniana, 22: 5-6.

Fatela, F. \& Taborda, R. 2002. Confidence limits of species proportions in microfossil assemblages. Marine Micropaleontology, 45: 169-174.

Frenzel, P., Tech, T. \& Bartholdy, J. 2005. Checklist and annotated bibliography of Recent Foraminiferida from the German Baltic Sea coast, In: Tyszka, J. (Ed.), Methods and applications in micropaleontology. Studia Geologica Polonica, 124: 67-86.

GKFF (Gemeinsames Komitee Flensburger Förde). 1973. Untersuchungen der Flensburger Förde: Wasseraustausch, Teilbericht 7: Selbstverlag, Amtshuset, Aabenraa, 129 pp.

Grobe, H. \& Fütterer, D. 1981. Zur Fragmentierung benthischer Foraminiferen in der Kieler Bucht (Westliche Ostsee). Meyniana, 33: 85-96.

Gustafsson, M. \& Nordberg, K. 1999. Benthic foraminifera and their response to hydrography, periodic hypoxic conditions and primary production in the Koljö fjord on the Swedish west coast. Journal of Sea Research, 41: 163-178.

Hallock, P. 2000. Larger foraminifera as indicators of coral-reef vitality. In: Martin, R.E. (Ed.), Environmental micropaleontology: The application of microfossils to environmental geology. Topics in biogeology, 15: $121-150$.

Hayward, B.W., Holzmann, M., Grenfell, H.R., Pawlowski, J. \& Triggs, C.M. 2004. Morphological distinction of molecular types in Ammonia - towards a taxonomic revision of the world's most commonly misidentified foraminifera. Marine Micropaleontology, 50: 237-271.

Heeger, T. 1990. Elektronenmikroskopische Untersuchungen zur Ernährungbiologie benthischer Foraminiferen. Berichte Sonderforschungbereich 313, University of Kiel, 21: 1-139. 
Hermelin, J.O. 1987. Distribution of Holocene benthic foraminifera in the Baltic Sea. Journal of Foraminiferal Research, 17: 62-73.

Jarke, J. 1961. Beobachtungen über Kalkauflösung an Schalen von Mikrofossilien in Sedimenten der westlichen Ostsee. Deutsche Hydrographische Zeitschrift, 14: 6-11.

Kreisel, K. \& Leipe, T. 1989. Zum Vorkommen rezenter benthischer Foraminiferen im Greifswalder Bodden. Wissenschaftliche Zeitschrift der Ernst-Moritz-Arndt-Universität Greifswald, mathematischnaturwissenschaftliche Reihe, 38: 98-104.

Kremling, K., Otto, C. \& Petersen, H. 1979. SpurenmetallUntersuchungen in den Förden der Kieler Bucht. Berichte aus dem Institut für Meereskunde an der CAU Kiel, 66, 38 pp.

Kucera, M. \& Malmgrem, B.A. 1998. Logratio transformation of compositional data - a resolution of the constant sum constraint. Marine Micropaleontology, 34: 117-120.

LANU. 2001. Deutsch-Dänische Messprogramm Flensburger Förde: Ergebnisse 1996-1997. Landesamt für Natur und Umwelt des Landes Schleswig-Holstein, Flintbek, 39 pp.

LANU. 2007. Sauerstoffmangel im bodennahen Wasser der westlichen Ostsee im September 2007, MURSYS Ostsee. Landesamt für Natur und Umwelt des Landes Schleswig-Holsteins, Flintbek. Available online at: http://www.bsh.de/de/Meeresdaten/Beobachtungen/MURSYSUmweltreportsystem/Mursys_031/seiten/oso27_01.jsp\#september 2007.

Levander, K.M. 1894. Materialen zur Kenntniss der Wasserfauna in der Umgebung von Helsingfors, mit besonderer Berücksichtung der Meeresfauna. I. Protozoa. Acta Societatis pro Fauna et Flora Fennica, 12: $1-115$.

Linke, P. \& Lutze, G.F. 1993. Microhabitat preferences of benthic foraminifera - a static concept or a dynamic adaptation to optimize food acquisition? Marine Micropaleontology, 20: 215-234.

Lutze, G.F. 1965. Zur Foraminiferen-Fauna der Ostsee. Meyniana, 15: $75-142$.

Lutze, G.F. 1968. Siedlungs-Strukturen rezenten Foraminiferen. Meyniana, 18: 31-34.

Lutze, G.F. \& Altenbach, A. 1991. Technik und Signifikanz der Lebenfärbung benthischer Foraminiferen mit Bengalrot. Geologisches Jahrbuch, 128: 251-265.

Lutze, G.F., Mackensen, A. \& Wefer, G. 1983. Foraminiferen der Kieler Bucht: 2. Salinitätsansprüche von Eggerella scabra (Williamson). Meyniana, 35: 55-65.

Matthäus, W. 2006. The history of investigation of salt-water inflows into the Baltic Sea - from the early beginning to recent results. Marine Science Reports, 65, IOW, Warnemünde, 81 pp. Available online at: $\mathrm{http}: / / \mathrm{www}$. io-warnemuende.de/research/mebe.html.

Meier, H.E.M., Feistel, R., Piechura, J. et al. 2006. Ventilation of the Baltic Sea deep water: a brief review of present knowledge from observations and models. Oceanologia, 48: 133-164.

Miller, A.A.L., Scott, D.B. \& Medioli, F. 1982. Elphidium excavatum (Terquem): ecophenotypic versus subspecific variation. Journal of Foraminiferal Research, 12: 116-144.

Moodley, L. \& Hess, Ch. 1992. Tolerance of infaunal benthic foraminifera for low and high oxygen concentrations. Biological Bulletin, 183: 94-98.

Möbius, K. 1889. Bruchstücke einer Rhizopodenfauna der Kieler Bucht. Physikalische Abhandlungen der Königlichen Akademie der Wissenschaften zu Berlin: 1-31.

Murray, J.W. 1989. Syndepositional dissolution of calcareous foraminifera in modern shallow-water sediments. Marine Micropaleontology, 15: $117-121$.

Murray, J.W. 2006. Ecology and application of benthic foraminifera, Cambridge University Press, Cambridge, $438 \mathrm{pp}$.

Murray, J.W. \& Bowser, S. 2000. Mortality, protoplasm decay rate, and reliability of staining techniques to recognize "living" foraminifera: a review. Journal of Foraminiferal Research, 30: 66-70.

Müller, G., Dominik, J. \& Reuther, R. 1980. Sedimentary record of environmental pollution in the Western Baltic Sea. Naturwissenschaften, 67: 595-600.

Nikulina, A. \& Dullo, W.-Ch. 2009. Eutrophication and heavy metal pollution in Flensburg Fjord: a reassessment after 30 years. Marine Pollution Bulletin, 58: 905-915.
Nikulina, A., Polovodova, I. \& Schönfeld, J. 2008. Foraminiferal response to environmental changes in Kiel Fjord, SW Baltic Sea: eEarth 3: 1-13. Available online at: www.electronic-earth.net/3/1/ 2008/.

Olsson, I. 1976. Distribution and ecology of foraminiferan Ammotium cassis (Parker) in some Swedish estuaries. Zoon, 4: 137-147.

Polovodova, I. \& Schönfeld, J. 2008. Foraminiferal test abnormalities in the western Baltic Sea. Journal of Foraminiferal Research, 38: 318-336.

Rheinheimer, G. 1970. Mikrobiologische und chemische Untersuchungen in der Flensburger Förde. Berichte der Deutschen Wissenschaftlichen Kommission für Meeresforschung, 21(1-4): 420-429.

Rhumbler, L. 1936. Foraminiferen der Kieler Bucht, gesammelt durch A. Remane, II. Teil. Kieler Meeresforschungen, 1: 179-242.

Rottgardt, D. 1952. Mikropaläontologische wichtige Bestandteile rezenter brackischer Sedimente an den Küsten Schleswig-Holsteins. Meyniana, 1: 169-228.

Schönfeld, J. \& Numberger, L. 2007a. Seasonal dynamics and decadal changes of benthic foraminiferal assemblages in the western Baltic (NW Europe). Journal of Micropaleontology, 26: 47-60.

Schönfeld, J. \& Numberger, L. 2007b. The benthic foraminiferal response to the 2004 spring bloom in the western Baltic Sea. Marine Micropaleontology, 65: 78-95.

Schulze, F.E. 1875. Rhizopodenstudien. Archiv für mikroskopische Anatomie, 11: 34-139.

Sen Gupta, B., Turner, R.E. \& Rabalais, N.N. 1996. Seasonal oxygen depletion in continental shelf-waters of Louisiana: Historical record of benthic foraminifers. Geology, 24: 227-230.

Vance, D.J., Culver, S.J., Corbett, D.R. \& Buzas, M.A. 2006. Foraminifera in the Albemarle estuarine system, North Carolina: distribution and recent environmental change. Journal of Foraminiferal Research, 36: 15-33.

Wahl, M. 1984. The fluffy sea anemone Metridium senile in periodically oxygen depleted surroundings. Marine Biology, 81: 81-86.

Wahl, M. 1985. The recolonisation potential of Metridium senile in an area previously depopulated by oxygen deficiency. Oecologia, 67: 255-259.

Wefer, G. 1976. Umwelt, Produktion und Sedimentation benthischer Foraminiferen in der westlichen Ostsee. Reports Sonderforschungsbereich 95 Wechselwirkung Meer-Meeresboden, 14: 1-103.

Widerlund, A. \& Andersson, P.S. 2006. Strontium isotopic composition of modern and Holocene mollusc shells as a paleosalinity indicator for the Baltic Sea. Chemical Geology, 232: 54-66.

\section{APPENDIX A. FAUNAL LIST OF SPECIES IN THIS STUDY}

Ammonia beccarii $($ Linné $)=$ Nautilus beccarii Linné, 1758; Schönfeld \& Numberger, 2007a, p. 52, pl. 1, fig. 2. (Note: molecular type T6 corresponding to Ammonia aomoriensis, Hayward et al., 2004, pp. 256-258, pl. II-IV).

Ammotium cassis $($ Parker $)=$ Lituola cassis Parker, 1870; Frenzel et al., 2005, p. 75, fig. 4, no. 3.

Eggerelloides scaber (Williamson) (note: Eggerella scabra of Lutze et al. (1983); Eggerelloides scabrus of Frenzel et al. (2005)).

Elphidium albiumbilicatum $\quad($ Weiss $)=$ Nonion pauciloculum Cushman subsp. albiumbilicatum Weiss, 1954; Frenzel et al., 2005, p. 73, fig. 2, no. 10; Schönfeld \& Numberger, 2007a, p. 52, pl. 1, fig. 4. (Note: Elphidium asklundi Brotzen, 1943 of Lutze (1965); Cribroelphidium albiumbilicatum of Frenzel et al. (2005)).

Elphidium excavatum excavatum $($ Terquem $)=$ Polistomella excavata Terquem, 1875, Miller et al., 1982, p. 127, pl. 1, figs 11-12; Schönfeld \& Numberger, 2007a, p. 52, pl. 1, figs 12-13. Elphidium excavatum clavatum (Cushman) 1930; Miller et al., 1982, p. 127, pl. 1, fig. 8; Schönfeld \& Numberger, 2007a, p. 52 , pl. 1 , figs $7-9$. 
Elphidium gerthi van Voorthuysen, 1957; Lutze, 1965, p. 159, pl. 15, fig. 45 (note: Cribrononion cf. gerthi of author).

Elphidium incertum $($ Williamson $)=$ Polystomella umbilicatula (Walker) var. incerta Williamson, 1858; Schönfeld \& Numberger, 2007a, p. 52, pl. 1, figs 5-6.
Elphidium williamsoni Haynes, 1973; Frenzel et al., 2005, p. 73, fig. 2, no. 8. (Note: Cribrononion cf. alvarezianum d'Orbigny, 1839 of Lutze (1965); Cribroelphidium williamsoni of Frenzel et al. (2005)).

\section{APPENDIX B}

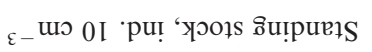

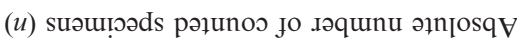

(S) ssəuપวฺ̣ sə̣๐ədS

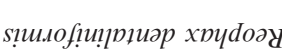

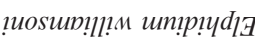

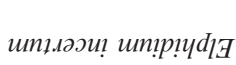

untasom un!p!y

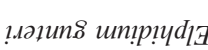

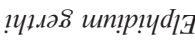

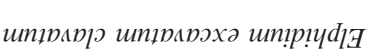

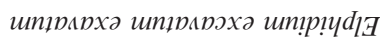

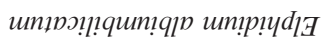

sıssp ип!пошин

!̣.ıрวэวq ричомин

गdurs

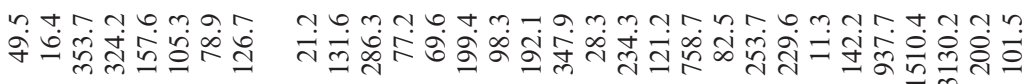

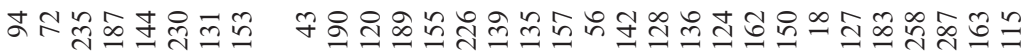

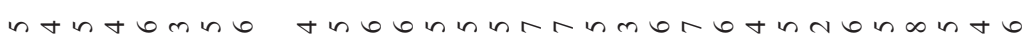

m?

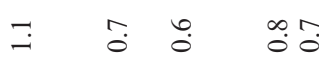

$\underset{i}{i}$

$\stackrel{\Upsilon}{\longrightarrow}$

$\hat{\sigma}$

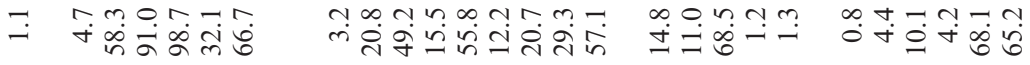

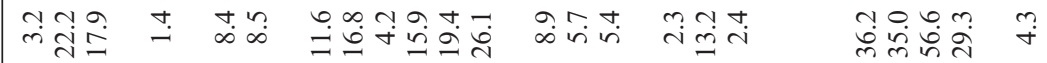

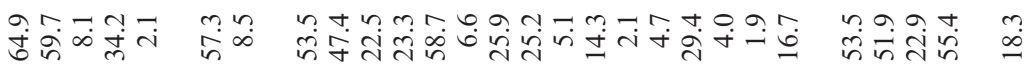

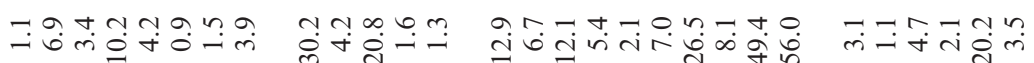

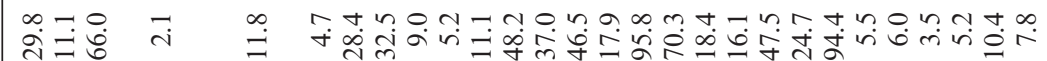

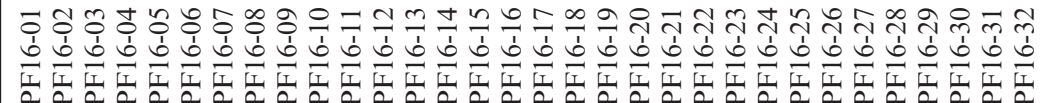

